\title{
Thyroid cancer following nuclear tests in French Polynesia
}

\author{
F de Vathaire ${ }^{*, 1,2,3}$, V Drozdovitch ${ }^{4,5}$, P Brindel ${ }^{1,2,3}$, F Rachedi ${ }^{6}$, J-L Boissin ${ }^{7}$, J Sebbag ${ }^{7}$, L Shan ${ }^{7}$, \\ F Bost-Bezeaud ${ }^{6}$, P Petitdidier ${ }^{8}$, J Paoaafaite', J Teuri', J Iltis', A Bouville ${ }^{5}$, E Cardis ${ }^{4}$, C Hill ${ }^{2}$ and F Doyon ${ }^{1,2,3}$ \\ 'Radiation Epidemiology Group, U I 0 I 8 INSERM, Institut Gustave Roussy, 39 rue Camille Desmoulins, Inserm, Villejuif F-94800, France; ${ }^{2}$ Institut Gustave \\ Roussy, Villejuif F-94800, France; ${ }^{3}$ Université Paris XI, Villejuif F-94800, France; ${ }^{4}$ International Agency for Research on Cancer, Lyon F-69008, France; \\ ${ }^{5}$ DHHS/NIHINCI/Division of Cancer Epidemiology and Genetics, MD 20892, USA; ${ }^{6}$ Centre Hospitalier Territorial Mamao, Tahiti, French Polynesia; \\ ${ }^{7}$ Endocrinologist, Tahiti, French Polynesia; ${ }^{8}$ Laboratoire Boz, Tahiti, French Polynesia; ${ }^{9}$ Institut de Recherche pour le Développement, Tahiti, French Polynesia
}

BACKGROUND: Between 1966 and 1974, France conducted 41 atmospheric nuclear tests in Polynesia, but their potential health effects have not previously been investigated.

METHODS: In a case-control study, we compared the radiation exposure of almost all the French Polynesians diagnosed with differentiated thyroid carcinoma between 1981 and $2003(n=229)$ to the exposure of 373 French Polynesian control individuals without cancer from the general population. Radiation exposures were estimated using measurements after the nuclear tests, age at time of each test, residential and dietary information.

RESULTS: The average thyroid dose before 15 years of age was about $1.8 \mathrm{mGy}$, and $5 \%$ of the cases and $3 \%$ of the controls received a dose above $10 \mathrm{mGy}$. Despite this low level of dose, and after adjusting for ethnic group, level of education, body surface area, family history of thyroid cancer and number of pregnancies for women, we observed an increasing risk $(P=0.04)$ of thyroid cancer with increasing thyroid dose received before age of 15 years, which remained after excluding non-aggressive differentiated thyroid micro-carcinomas. This increase of risk per unit of thyroid radiation dose was higher $(P=0.03)$ in women who later experienced four or more pregnancies than among other women.

CONCLUSION: The risk estimate is low, but is based on limited exposure data. The release of information on exposure, currently classified, would greatly improve the reliability of the risk estimation.

British Journal of Cancer (2010) I 03, III5-II2I. doi:10.1038/sj.bjc.6605862 www.bjcancer.com

Published online 31 August 2010

(c) 2010 Cancer Research UK

Keywords: differentiated thyroid carcinoma; nuclear test; French Polynesia; radiation-induced cancer

Between 1945 and 1980, the United States, the Soviet Union, the United Kingdom, France and China carried out 520 atmospheric tests of nuclear weapons totalling the explosive equivalent of 440 megatons (Boice, 2006). After a nuclear explosion, radioactive debris is initially swept upwards and then dispersed in the directions of the prevailing winds. Local deposition of radionuclides fallout from radioactive clouds can expose populations to external and internal irradiation. External irradiation exposure is mainly from penetrating $\gamma$-rays emitted by particles on the ground, whereas the main source of internal irradiation is consumption of contaminated food and water.

Between 1966 and 1974, France conducted 41 atmospheric nuclear weapon tests in French Polynesia (FP) (Martin, 2007). This consists of four archipelagos: Société, Marquises, Australes and Tuamotu-Gambier, and 121 atolls or islands covering $4000 \mathrm{~km}^{2}$ of land spread over 4 millions $\mathrm{km}^{2}$ of the Pacific Ocean (Figure 1). Tests took place in Mururoa and Fangataufa, in the southeastern part of the Tuamotu-Gambier archipelago.

To evaluate the potential function of atmospheric nuclear tests fallout in a high incidence of thyroid cancer observed in FP (de Vathaire et al, 2000), a population-based case-control study of

*Correspondence: Dr F de Vathaire; E-mail: florent.devathaire@igr.fr Received 18 February 2010; revised 27 July 2010; accepted 3 August 20।0; published online 31 August 2010 thyroid cancer was performed. We have shown previously that a high level of education (Brindel et al, 2008), tallness (Brindel et al, 2009), a high body mass index (Brindel et al, 2009), a family history of thyroid cancer (Brindel et al, 2010) and, in women, a large number of pregnancies (Brindel et al, 2010) were associated with an increased risk of thyroid cancer in this population.

\section{MATERIALS AND METHODS}

In 1979, the South Pacific Commission recommended the creation of a cancer registry in FP (Henderson et al, 1982). In 1980-1984, two partial registries were in operation, maintained, respectively, by clinicians and by pathologists. The cancer incidence registry of FP was officially created in 1984 (Laudon, 1989). In 1996-1998, we verified and completed the registry data on the basis of all the medical evacuation files, insurance records and hospital and pathological laboratory files available in FP. We also wrote to the hospitals in France, New Zealand and Hawaii, where patients had been evacuated from FP, asking for their list of patients from Polynesia, and for a confirmation of cancer diagnosis. A total of 30000 records were examined, and 539 cancers diagnosed after 1984 among patients born and living in FP, which had not been included in the cancer registry of FP, were identified during this period (de Vathaire et al, 2000). An additional survey, limited to thyroid cancer was also performed in 2002-2005, in order to 


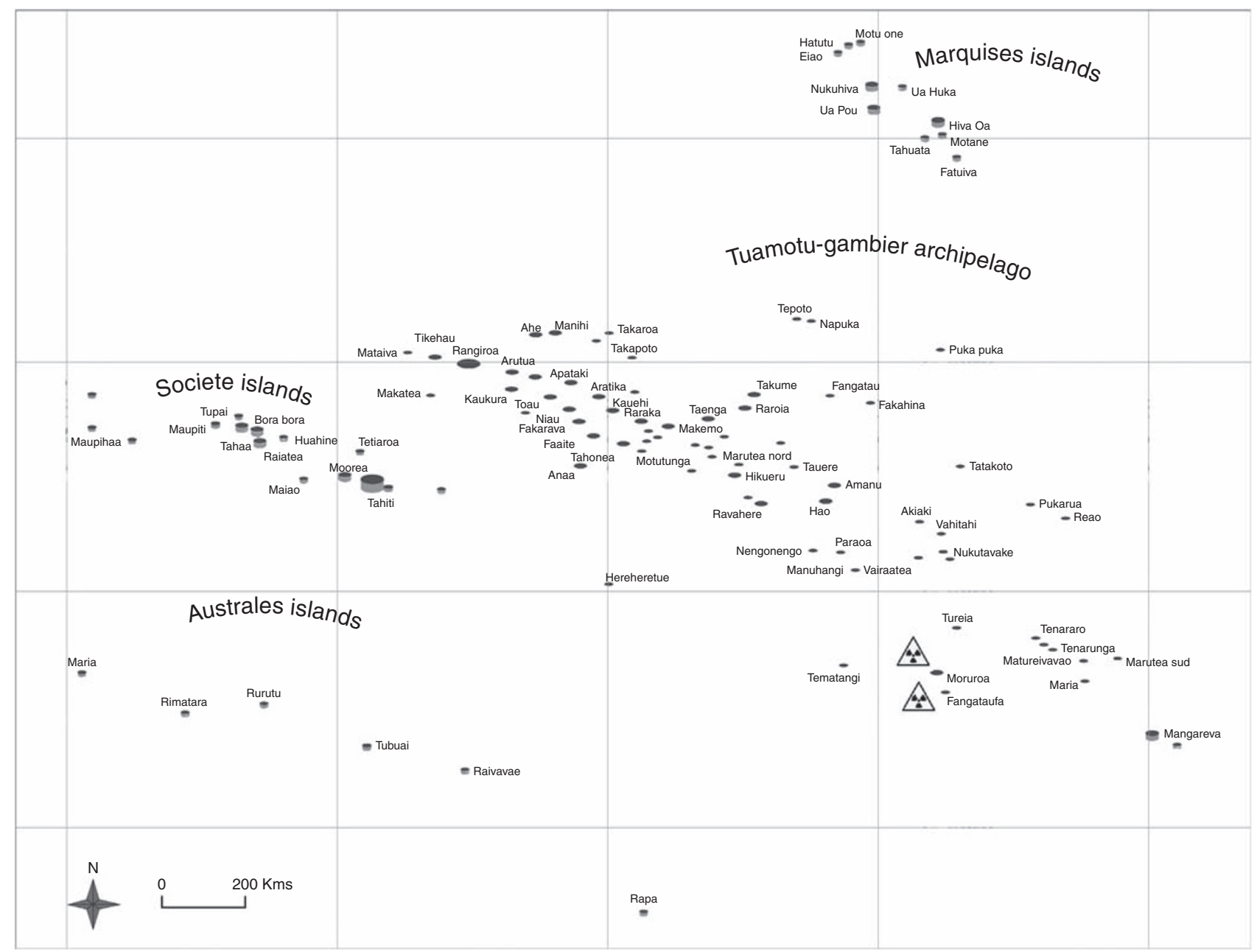

Figure I Map of French Polynesia, the symbol $\Delta$ indicates the two nuclear test sites.

complete registry data with incident cases diagnosed up to 2002 in data from medical insurance files, and records from the four endocrinologists in Tahiti.

All patients diagnosed in 1981-2003 with thyroid cancer at the age of 55 years or less, born and resident in FP at time of diagnosis, were eligible. Four patients aged from 56 to 62 years at diagnosis, one case diagnosed in 1979 and two in 2004, were included by error and were kept in the analysis. Incomplete histological information was completed from the two histopathology laboratories in Tahiti and from the medical files of endocrinologists.

Of the 255 eligible thyroid cancer cases, $26(10 \%)$ were not interviewed because they had died $(n=14)$, could not be located $(n=6)$, refused to participate $(n=5)$ or were too ill to be interviewed $(n=1)$. The final study population consisted of 229 cases (95\% of the living potential cases).

For each eligible case, the two controls nearest in terms of date of birth $(+I-3$ months for the first interviewed controls, changed in $+I-20$ days afterwards) and matched on sex were identified from the French Polynesian birth registry. Among 458 eligible controls, 85 were not interviewed: 9 had died, 29 could not be located, 29 refused to participate, 2 were too ill to be interviewed and 16 had left FP. A total of 373 controls ( $83 \%$ of the alive potential controls) were interviewed. At the end of the interviews, 169 cases had 2, 35 cases had 1 and 25 cases had no interviewed controls. Each of these 25 cases was matched to a control initially matched to another case, of the same sex and a close date of birth, who had two interviewed controls; the control reassigned to the case with no controls, and then not used for the originally matched case. Matching on birth date was relaxed if necessary. Finally, of the 229 interviewed cases, 85 were matched to one $(37 \%)$ and 144 with two controls (63\%). The difference in date of birth between a case and his/her control(s) was $<20$ days for 270 controls, and 21 - 90 days for 88 controls and between 91 days and 21 months for 15 controls.

Cases and controls were interviewed face to face on ethnic group, education, occupation, places of residence, weight history, personal and familial history of thyroid disease and cancer, gynaecologic and reproductive history, medical X-ray exposure and diet at the time of the interview and during childhood. The exposure of each case and his/her matched controls was taken into account up to the age at diagnosis of the case.

Of the cases, $89 \%$ were women and $68.5 \%$ were under age 15 years in 1966 or born during the tests, that is potentially exposed during childhood; $26.6 \%$ were aged 15 years or over in 1966 and $4.8 \%$ were born in 1975 or later, that is never exposed (Table 1). Thyroid micro-carcinomas discovery depends on clinical investigations, which may have been more intense in the exposed population; a sensitivity analysis was, therefore, planned for, excluding cases with unifocal tumours of $10 \mathrm{~mm}$ or less or of unknown size and without extra-thyroidal invasion.

The deposition densities of radionuclides on each island where one study subject resided at the time of each test were reconstructed on the basis of measurements of the radioactivity, on information on the source of drinking water and on 
Table I Description of thyroid cancer cases, French Polynesia

\begin{tabular}{|c|c|c|}
\hline \multirow[b]{2}{*}{ Characteristics } & \multicolumn{2}{|c|}{ Cases $(N=229)$} \\
\hline & $N$ & $\%$ \\
\hline \multicolumn{3}{|l|}{ Sex } \\
\hline Men & 26 & 11.4 \\
\hline Women & 203 & 88.6 \\
\hline \multicolumn{3}{|c|}{ Age at time of first test (years) } \\
\hline $15+$ & 61 & 26.6 \\
\hline $0-14$ & 124 & 54.1 \\
\hline Born during tests & 33 & 14.4 \\
\hline Born after tests & 11 & 4.8 \\
\hline \multicolumn{3}{|c|}{ Age at diagnosis (years) } \\
\hline $10-19$ & 8 & 3.5 \\
\hline $20-29$ & 39 & 17.0 \\
\hline $30-39$ & 76 & 33.2 \\
\hline $40-49$ & 63 & 27.5 \\
\hline $50-62$ & 43 & 18.8 \\
\hline \multicolumn{3}{|l|}{ Histology } \\
\hline Papillary & 176 & 76.9 \\
\hline Follicular & 53 & 23.1 \\
\hline \multicolumn{3}{|l|}{ Tumour size (mm) } \\
\hline$\leqslant 10$ & 106 & 52.2 \\
\hline $11-40$ & 75 & 36.9 \\
\hline$>40$ & 22 & 10.8 \\
\hline Unknown & 26 & - \\
\hline \multicolumn{3}{|l|}{ Multifocal tumour } \\
\hline No & 128 & 61.0 \\
\hline Yes & 82 & 39.0 \\
\hline Unknown & 19 & - \\
\hline \multicolumn{3}{|l|}{ Extra-thyroidal invasion } \\
\hline No & 191 & 83.4 \\
\hline Yes & 38 & 16.6 \\
\hline
\end{tabular}

meteorological information. This was performed using measurements of total radioactivity in filtered air, of ${ }^{131} \mathrm{I}$ and ${ }^{137} \mathrm{Cs}$ in fresh milk and of total $\gamma$-activity and ${ }^{137} \mathrm{Cs}$ in vegetables and fish (Drozdovitch et al, 2008). Estimation of the water level in cisterns before each test, size of the cisterns and information on wind and rain were also used. For each study subject, the total thyroid dose was the sum of the thyroid doses reconstructed for each test, taking into account age, source of drinking water and data collected in the diet questionnaire (Drozdovitch et al, 2008). The individual consumption of each foodstuff at a given age was deduced from the information on consumption during childhood obtained in the interview, using age-specific scaling factors. Dose reconstruction was conducted without knowledge of the case or control status of the subject.

\section{Statistical analysis}

Data were analysed using conditional logistic regression (Breslow and Day, 1987) with the Epicure epidemiological software (Preston et al, 1993) and SAS V8.1. To investigate the relationship between the thyroid radiation dose and the risk of thyroid cancer, we compared nested models, using likelihood-ratio tests (Moolgavkar and Venzon, 1987). Tests for linear trend (Breslow and Day, 1987) were also performed. All analyses were adjusted for ethnic group: Polynesian $v s$ mixed origin (54\% of cases and $55 \%$ of controls were Polynesian), because Maoris are at higher risk of thyroid cancer than others in FP. The analysis of the effect of radiation on the risk of thyroid cancer was systematically adjusted for level of
Table 2 Characteristics of the thyroid dose received before age 15 years

\begin{tabular}{|c|c|c|}
\hline Characteristic & $\begin{array}{l}\text { Thyroid cancer } \\
\text { cases (229) (\%) }\end{array}$ & $\begin{array}{l}\text { Controls } \\
\text { (373) (\%) }\end{array}$ \\
\hline \multicolumn{3}{|l|}{ Year of exposure } \\
\hline 1966 & 15 & 10 \\
\hline 1967 & 2 & 2 \\
\hline 1968 & 6 & 7 \\
\hline 1969 & 0 & 0 \\
\hline 1970 & 3 & 4 \\
\hline |97| & 8 & 7 \\
\hline 1972 & । & । \\
\hline 1973 & 7 & 7 \\
\hline 1974 & 58 & 62 \\
\hline \multicolumn{3}{|c|}{ Island or archipelago of residence } \\
\hline Tahiti and Moorea & 69 & 84 \\
\hline Other Société islands & | | & 7 \\
\hline Australes & 2 & I \\
\hline Marquises & 3 & 3 \\
\hline Tuamotu-Gambier & 15 & 5 \\
\hline \multicolumn{3}{|l|}{ Source } \\
\hline Leafy vegetables & 74 & 71 \\
\hline Milk & | | & 14 \\
\hline Inhalation & 6 & 4 \\
\hline Cistern rain water & 3 & 5 \\
\hline Other foodstuffs & । & 2 \\
\hline External irradiation & 5 & 4 \\
\hline \multicolumn{3}{|l|}{ Radionuclides } \\
\hline$|3|$ & 75 & 78 \\
\hline${ }^{132} \mathrm{I},{ }^{133} \mathrm{I},{ }^{135} \mathrm{I},{ }^{132} \mathrm{Te}$ & 18 & 16 \\
\hline${ }^{137} \mathrm{Cs}$ & 2 & 2 \\
\hline External irradiation & 5 & 4 \\
\hline
\end{tabular}

education, height, body mass index, familial history of thyroid cancer and number of pregnancies. The analysis was also adjusted for the interviewer. All significance tests are two sided.

\section{RESULTS}

The average lifetime thyroid dose from exposure to radioactive fallout was $2.6 \mathrm{mGy}$ both for cases and for controls with ranges $0-39 \mathrm{mGy}$ for the cases and $0-36 \mathrm{mGy}$ for the controls. Most of the dose was received before age 15 years. Before 15 years, the average doses received by the cases and by the controls were 1.8 and $1.7 \mathrm{mGy}$, respectively, with ranges $0-38$ and $0-36$. The 73 cases who had received $>1 \mathrm{mGy}$ to the thyroid had received an average of $5.4 \mathrm{mGy}$, whereas the 123 controls had received an average of $4.7 \mathrm{mGy}$. A dose of $10 \mathrm{mGy}$ or more was received by $5.2 \%$ of the cases and $3.2 \%$ of the controls. Table 2 describes the characteristics of thyroid radiation exposure in terms of year and site of residence, source and type of radionuclide. For both cases and controls, most of the total thyroid doses resulted from exposures in 1974, in the population residing in Tahiti or Moorea, and the most important source of exposure was leafy vegetables. Intake of ${ }^{131}$ I contributed to $75 \%$ and $78 \%$ of the mean thyroid dose received before age 15 years, respectively, by the cases and the controls.

The risk of thyroid cancer was found to increase significantly with the thyroid dose received before age 15 years $(P$-value for trend 0.04$)$; this result was persisting when micro-carcinomas and tumours of unknown size were excluded ( $P$ for trend 0.02; Table 3). The excess relative risk per Gray (ERR/Gy) estimated by a linear model was 55 (95\% confidence interval (CI): -14 to 288$)$. Ten cases ( 9 men and 1 woman) and 12 controls (12 men) had worked 
Table 3 Thyroid cancer risk according to dose before age 15 years and to work at nuclear sites

Total population

(229 cases and 373 controls)
Excluding unifocal micro-carcinomas, cancers of unknown size and their controls (14I cases/23I controls)

\begin{tabular}{|c|c|c|c|c|c|c|}
\hline Exposure & Cases/controls & $\begin{array}{c}\text { OR } \\
(95 \% \mathrm{Cl})^{\mathrm{a}}\end{array}$ & $\begin{array}{l}\text { P-value } \\
\text { for trend }\end{array}$ & Cases/controls & $\begin{array}{c}\text { OR } \\
(95 \% \mathrm{CI})^{a}\end{array}$ & $\begin{array}{l}P \text {-value } \\
\text { for trend }\end{array}$ \\
\hline \multicolumn{7}{|c|}{ Thyroid dose before age 15 years } \\
\hline $1-9.9 \mathrm{mGy}$ & $61 / 111$ & $1.0(0.5-1.9)$ & 0.04 & $39 / 74$ & I.I $(0.5-2.6)$ & 0.02 \\
\hline $10-19.9 \mathrm{mGy}$ & $7 / 9$ & $3.3(0.8-14)$ & & $5 / 6$ & $6.2(0.9-4 I)$ & \\
\hline $20-39 \mathrm{mGy}$ & $5 / 3$ & $5.7(0.8-45)$ & & $4 / 2$ & $11.6(1.0-132)$ & \\
\hline Yes & $10 / 12$ & $1.0(0.3-3.5)$ & 0.9 & 9/9 & $1.5(0.4-5.8)$ & 0.7 \\
\hline
\end{tabular}

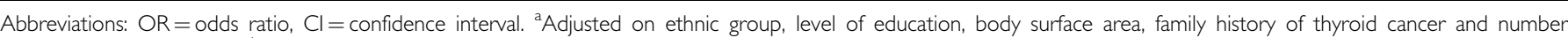

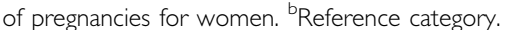

Table 4 Risk of thyroid cancer in women according to radiation dose to the thyroid before age 15 years and to the number of pregnancies

\begin{tabular}{|c|c|c|c|c|c|c|c|c|}
\hline & \multicolumn{4}{|c|}{$\begin{array}{l}\text { Four pregnancies or more } \\
\text { ( } 117 \text { cases and } 143 \text { controls) }\end{array}$} & \multicolumn{4}{|c|}{$\begin{array}{l}\text { Less than four pregnancies } \\
\text { (86 cases and I83 controls) }\end{array}$} \\
\hline & Cases/controls & $O R^{a}$ & $(95 \% \mathrm{Cl})$ & $P$-value & Cases/controls & $O R^{a}$ & $(95 \% \mathrm{Cl})$ & $P$-value \\
\hline \multicolumn{9}{|c|}{ Thyroid radiation dose before age 15 years } \\
\hline$<$ ImGy & $83 / 115$ & $1^{\mathrm{b}}$ & - & & $54 / 102$ & $1^{\mathrm{b}}$ & - & \\
\hline I -9.9mGy & $28 / 26$ & 1.5 & $(0.6-3.7)$ & & $27 / 77$ & 0.7 & $(0.3-1.5)$ & \\
\hline 10 mGy or more & $6 / 2$ & 11.2 & $(1.1-112)$ & & $5 / 9$ & 2.2 & $(0.4-12)$ & \\
\hline
\end{tabular}

Abbreviations: $\mathrm{OR}=$ odds ratio, $\mathrm{Cl}=$ confidence interval. ${ }^{2}$ Adjusted on ethnic group, level of education, height, body mass index, menopausal status at time of cancer diagnosis and familial history of thyroid cancer. ${ }^{b}$ Reference category. $P$-value for interaction between the number of pregnancies (as a continuous variable) and the radiation dose: $P=0.03$.

at nuclear tests sites, but this was not found to increase thyroid cancer risk (Table 3 ).

We found a significant interaction $(P=0.03)$ between the effects of the radiation dose and the number of pregnancies, both being considered as continuous variables. The increase in risk with the dose was greater among women who had four pregnancies or more than among women with less than four pregnancies (Table 4), which was also observed when thyroid micro-carcinomas and cancers of unknown size were excluded ( $P$-value for interaction $<0.01)$.

\section{DISCUSSION}

Given the geographic isolation of FP and the high standard of the local public health system, it seems unlikely that many cases could have escaped detection by all our sources of information. Thyroid cancer being rarely lethal, the restriction of the study to cases alive at the time of interview is not likely to have been a major source of bias. The French Polynesian population was not aware of the geographic distribution of the fallout during the 1966-1974 period. They were also unaware of the fact that leafy vegetables were the most contaminated foodstuff, that drinking rain water was a source of exposure and that fish consumption was not. The declared consumption of each subject is, therefore, unlikely to be biased by his/her status of case or control.

Controls were selected randomly from the Polynesian registry of birth, which includes all persons born in FP. Among the 458 potential controls, 85 may not be interviewed, who were born earlier than the interviewed controls (1955 in average, vs 1957, $P=0.09$ ), but of similar gender and place of birth distribution. As analysis was performed using conditional logistic regression, matched on birth date, this potential source of bias was controlled. Matching on age was not as close as originally planned, but exclusion of the 25 strata corresponding to the reassigned controls and their cases did not modify the results, the OR for thyroid doses of $10-19$ and $20 \mathrm{mSv}$ or more, being, respectively, 5.6 and 3.3, instead of 5.7 and 3.3 (Table 3).

Our thyroid dose estimates are similar to those estimated by the French Army in 1977 and 1997 on the basis of the same measurements (Bourgès, 1998). The small number of available measures for dose reconstruction probably led us to underestimate the geographical variability in radioactive deposits and thus in thyroid doses. This is more likely to have introduced uncertainties and decreased power of our study than to have introduced a bias. A thorough compilation of the results of all radiological monitoring that have been carried out in FP in 1966-1974 would greatly improve the reliability and the precision of the dose estimates. Recently, the French Army has published new estimations of the radiation dose to thyroid for the six tests, which led to the highest fallout (Jurien de la Gravière, 2006). Those estimations are higher than those reported in 1998 (Bourgès, 1998), but we were not able to use them because they do not take into account the variability in food consumption and they exist only for six islands or atolls.

We observed an ERR/Gy of 55 (95\% CI: -14 to 288) for thyroid cancers occurring about 25 years on average after ${ }^{131} \mathrm{I}$ exposure. Other nuclear test sites have been studied, mainly those from the United States and Soviet Union. The United States performed 66 nuclear tests between 1946 and 1958 on Bikini and Enewetak atolls in the Marshall Islands, resulting in radioactive fallout contamination of a number of neighbourhood atolls. Estimated thyroid doses were very high in some atolls: $6800 \mathrm{mGy}$ for 1-yearold infants at the time of the Bravo nuclear test of 1954 at Utirik, 
half of this dose at Ailuk and Mejit and 2\% of this dose, that is still $120 \mathrm{mGy}$, in the most distant atolls such as Majuro (Simon and Graham, 1997). In 1993-97, a thyroid screening was performed in about $60 \%$ of the living potentially exposed population. Thyroidnodules prevalence was found to be frequent and to be linked to iodine intake rather than to external radiation exposure (Takahashi et al, 1999). On the basis of a total of 57 cases (30 prevalent screened cases +27 previously diagnosed cases), there was a suggestion $(P=0.15)$ of a relationship between thyroid dose and thyroid cancer (Takahashi et al, 2003).

In a cohort of 2497 subjects having lived near the Nevada site during the 90 atmospheric US nuclear tests and having received an average radiation dose of $120 \mathrm{mGy}$, eight thyroid cancers were observed, too few for a dose response analysis, but the ERR/Gy for all thyroid neoplasms was 13.0 (95\% CI: 2.7-68.7) (Lyon et al, 2006). On the other hand, an ecological analysis of thyroid cancer incidence rate, based on SEER data, estimated the ERR/Gy to be 2.4 ( $95 \%$ CI: -0.5 to 5.6) for the dose received before age of 1 year, but no increase for that received afterwards (Gilbert et al, 2010).

In several villages near the nuclear test site of Semipalatinsk in Kazakhstan, where the Soviet Union performed 116 atmospheric tests in 1949-1962, the cumulative average total radiation dose to the thyroid was $>1 \mathrm{~Gy}$ (Stepanenko et al, 2006). Thyroid disease prevalence among 2994 residents of eight villages was ascertained by ultrasound screening. Prevalence of papillary cancer $(n=26)$ was low and not significantly associated with radiation dose (Land et al, 2008). Thyroid-nodule prevalence (165 cases among 894 residents) was found to be 1.4 times (95\% CI: $1.1-1.9$ ) higher in Ozyorsk near the Mayak nuclear weapons facility in Russia, than in non-exposed populations, but only eight thyroid neoplasms have been observed so far, despite thyroid doses, which could reach several Grays (Mushkacheva et al, 2006). From 1944 through 1957, approximately $2.73 \times 10^{16} \mathrm{~Bq}$ of ${ }^{131} \mathrm{I}$ were released from the Hanford Site in Washington State into the atmosphere, leading to cumulative thyroid doses reaching several Grays (Shipler et al, 1996). In 1992-1997, 3440 individuals were screened for thyroid pathology and their thyroid doses estimated (median, $97 \mathrm{mGy}$; mean, $174 \mathrm{mGy}$ ). A total of 249 subjects were diagnosed with benign thyroid nodules, the prevalence not varying with estimated dose. Only 19 thyroid cancers were observed (Davis et al, 2004).

Although, in all these studies, estimated radiation doses were much higher than in our study, reaching levels of one or several Grays, their results are very variable. The small numbers of thyroid cancers may explain the lack of a significant function of thyroid radiation in certain studies (Khokhryakov et al, 2002; Takahashi et al, 2003; Davis et al, 2004; Lyon et al, 2006; Mushkacheva et al, 2006). This finds support in the fact that, with the exception of Marshall Islands (Takahashi et al, 2003) and Hanford studies (Davis et al, 2004), thyroid nodules (which were more frequent than thyroid cancer) were found to increase when increasing thyroid radiation (Khokhryakov et al, 2002; Lyon et al, 2006; Mushkacheva et al, 2006). The lack of significant dose response in the Hanford studies could be due to low dose rate (Davis et al, 2004), but the results from the Marshall studies remain unexplained (Takahashi et al, 2003). However, none of these studies controlled for other risk factors for thyroid cancer. In fact, most of the information on thyroid cancer risk after exposure to ${ }^{131}$ I comes from studies of the Chernobyl accident. The largest case-control study in Belarus and Russian Federation (Cardis et al, 2005) estimated ERR/Gy as varying between 4.5 (95\% CI: $2.1-8.5)$ and $7.4(3.1-16.3)$ for exposure before age 15 years, depending on the model used. Another such study with 66 cases and 132 controls (Kopecky et al, 2006), two geographical studies (Jacob et al, 2006; Likhtarov et al, 2006) and one cohort study (Tronko et al, 2006) including 13127 children from Ukraine found compatible results: an ERR/Gy of 48.7 (94\% CI: 4.8-1151), of 19 (95\% CI: $11-27)$, of 8.0 (95\% CI: $4.6-15)$ and of 5.3 (95\% CI: $1.7-27.5)$, respectively. These estimates are in agreement with the
ERR/Gy of 7.7 (95\% CI: 2.1-28.7) for external irradiation of thyroid in a meta-analysis of seven studies (Ron et al, 1995) and lower than, although compatible with, the ERR/Gy of 55 (95\% CI: -14 to 288 ) that we have observed. These differences may be related to differences in latency period: 10 years on average after Chernobyl vs 30 years in Polynesia, and in dose: higher in Chernobyl than in Polynesia. The average latency period of thyroid cancers after childhood irradiation ranges between 20 and 40 years (Boice, 2006). Chernobyl studies have not yet had a long enough follow-up to observe the full effects of thyroid irradiation.

Low doses may be more carcinogenic than predicted from studies of higher doses. The median thyroid radiation dose was much lower in the Russian Federation than in Belarus (39vs $356 \mathrm{mGy})$, and the ERRs/Gy were 32 (95\% CI: 1.3-761) vs 5.1 (95\% CI: 2.9-8.9) (Cardis et al, 2005). In the other population-based case-control study (Kopecky et al, 2006), the median radiation dose received by controls was $16 \mathrm{mGy}$, and the ERR/Gy was 49 (95\% CI: 4.8-1151). Similarly, a recent update of the follow-up of the Israeli cohort of 10834 children who received radiotherapy for tinea capitis in the 1950s (average dose: $55 \mathrm{mGy}$, from 4.5-495 mGy) showed an overall ERR/Gy of 20.2 (95\% CI: 11.3-32.3) (Sadetzki et al, 2006).

In Chernobyl, risk was much higher in the population living in iodine-deficient areas, who had not been given post-exposure iodine (Cardis et al, 2005). This has been attributed to continuous thyroid stimulation (Ron, 2007). However, this does not explain the high, although non-significant, ERR/Gy observed in the French Polynesian population, as this population is not diet deficient in iodine. In addition, in Marshall studies, dietary iodine intake was an individual risk factor, rather than a factor interacting with radiation (Takahashi et al, 2003).

The interaction between the number of pregnancies and the radiation exposure in childhood on thyroid cancer risk is a new finding, no other study has included women with such a high average number of pregnancies. As during the first trimester, the foetus is dependent on maternal thyroxin and later on the direct supply of maternal iodine for its own thyroxin production (Sack, 2003), maternal thyroid activity is increased during pregnancy. Estrogens, which are elevated during pregnancy, could have a function in the proliferation of malignant thyroid cells (Glinoer et al, 1990; Manole et al, 2001). Repeated pregnancies could increase the risk of thyroid cancer after childhood irradiation, by revealing radiation-induced DNA damages, which would have remained silent without pregnancies.

Nuclear site work was not associated with an increased risk of thyroid cancer, which is not unexpected: as this is neither increased by medical ${ }^{131} \mathrm{I}$ administration (Dickman et al, 2003) nor by external irradiation (Ron et al, 1995) in adulthood. In addition, $89 \%$ of thyroid cancers in our study occurred in females and few women worked at the nuclear sites.

We found that the mean thyroid dose to the thyroid received in FP as a consequence of the atmospheric nuclear tests was low, that thyroid cancer risk increased with increasing dose, but that as these were based on a limited number of measurements, they are uncertain and probably underestimated. The release of classified material on the radiological situation in FP after the tests would help in refining the dose estimates.

\section{ACKNOWLEDGEMENTS}

This study was supported by the Association pour la Recherche contre le Cancer, the Ligue Nationale Contre le Cancer, the Direction Générale de la Santé, the Comité de radioprotection de Electricité de France, Agence Française de Sécurité Sanitaire et Environnementale et du Travail and CHILD-THYR EEC programme. We thank $\mathrm{Dr} \mathrm{Ph}$ Morales, $\mathrm{Dr} \mathrm{P}$ Giraud, Dr P Didiergeorge, Dr M Brisard, Dr G Soubiran, Dr B Caillou, JM Bidard, A Merceron, ML Vanizette, P Dupire, M Berges, 
Dr J Ienfa, Dr G de Clermont, N Cerf, B Oddo, M Bambridge, C Baron, A Mouchard-Rachet, Dr O Simonet, Dr D Lamarque, Dr Vabret, Dr J Delacre, MP Darquier and J Leninger.

Authors' contributions: FDV (PhD) and FD, as principal investigators, designed and monitored the study, obtained ethical approval and were involved in the analysis and interpretation of results and in the writing of the paper. FDV, FD and $\mathrm{CH}$ wrote the paper. $\mathrm{VD}(\mathrm{PhD})$ and $\mathrm{AB}(\mathrm{PhD})$ conducted the dose estimations. $\mathrm{PB}$ (MD) participated in the management of the study data and analysis. FR (MD), J-LB (MD), JS (MD) and LS (MD) helped

\section{REFERENCES}

Boice JD (2006) Thyroid disease 60 years after Hiroshima and 20 years after chernobyl. JAMA 295: 1060-1062

Bourgès G (1998) Radiological consequences of the atmospheric tests on the Islands of French Polynesia from 1966-1974, In: Impact Géomécanique et Radiologique des Essais Nucléaires à Mururoa et Fangataufa (Polynésie française). DIRECEN CEA (Eds). La Documentation française: Paris, France

Breslow NE, Day NE (1987) Fitting models to grouped data. In: Statistical Methods in Cancer Research: The Design and Analysis of Cohort Studies. Vol 82, pp 119-176. IARC scientific publication: Lyon, France

Brindel P, Doyon F, Bourgain C, Rachédi F, Boissin JL, Sebbag J, Shan L, Bost-Bezeaud F, Petitdidier P, Paoaafaite J, Teuri J, de Vathaire F (2010) Family history of thyroid cancer and the risk of differentiated thyroid cancer in French Polynesia. Thyroid 20: 393-400

Brindel P, Doyon F, Rachédi F, Boissin JL, Sebbag J, Shan L, Chungue V, Bost-Bezeaud F, Petitdidier P, Paoaafaite J, Teuri J, de Vathaire F (2009) Anthropometric factors in differentiated thyroid cancer in French Polynesia: a case-control study. Cancer Causes Control 20: $581-590$

Brindel P, Doyon F, Rachédi F, Boissin JL, Sebbag J, Shan L, Chungue V, Sun LY, Bost-Bezeaud F, Petitdidier P, Paoaafaite J, Teuri J, de Vathaire F (2008) Menstrual and reproductive factors in the risk of differentiated thyroid carcinoma in native women in French Polynesia: a populationbased case-control study. Am J Epidemiol 167: 219-229

Cardis E, Kesminiene A, Ivanov V, Malakhova I, Shibata Y, Khrouch V, Drozdovitch V, Maceika E, Zvonova I, Vlassov O, Bouville A, Goulko G, Hoshi M, Abrosimov A, Anoshko J, Astakhova L, Chekin S, Demidchik E, Galanti R, Ito M, Korobova E, Lushnikov E, Maksioutov M, Masyakin V, Nerovnia A, Parshin V, Parshkov E, Piliptsevich N, Pinchera A, Polyakov S, Shabeka N, Suonio E, Tenet V, Tsyb A, Yamashita S, Williams D (2005) Risk of thyroid cancer after exposure to 131I in childhood. J Natl Cancer Inst 97: $724-732$

Davis S, Kopecky KJ, Hamilton TE, Onstad L, Hanford Thyroid Disease Study Team (2004) Thyroid neoplasia, autoimmune thyroiditis, and hypothyroidism in persons exposed to iodine 131 from the Hanford nuclear site. JAMA 292: 2600-2613

de Vathaire F, Le Vu B, Challeton de Vathaire C (2000) Thyroid cancer in French Polynesia between 1985 and 1995: influence of atmospheric nuclear bomb tests performed at Mururoa and Fangataufa between 1966 and 1974. Cancer Causes Control 11: 59-63

Dickman PW, Holm LE, Lundell G, Boice Jr JD, Hall P (2003) Thyroid cancer risk after thyroid examination with 131I: a population-based cohort study in Sweden. Int J Cancer 106: 580-587

Drozdovitch V, Bouville A, Doyon F, Brindel P, Cardis E, de Vathaire F (2008) Reconstruction of individual radiation doses for a casecontrol study of thyroid cancer in French Polynesia. Health Phys 94: $418-433$

Gilbert ES, Huang L, Bouville A, Berg CD, Ron E (2010) Thyroid cancer rates and 131I doses from nevada atmospheric nuclear bomb tests: an update. Radiat Res 173: 659-664

Glinoer D, de Nayer P, Bourdoux P, Lemone M, Robyn C, van Steirteghem A, Kinthaert J, Lejeune B (1990) Regulation of maternal thyroid during pregnancy. J Clin Endocrinol Metab 71: 276-287

Henderson BE, Forter F, Kolonel LN (1982) Cancer in polynesians. NCI Monogr 62: $73-78$

Jacob P, Bogdanova TI, Buglova E, Chepurniy M, Demidchik Y, Gavrilin Y, Kenigsberg J, Meckbach R, Schotola C, Shinkarev S, Tronko MD Ulanovsky A, Vavilov S, Walsh L (2006) Thyroid cancer risk in areas of Ukraine and Belarus affected by the Chernobyl accident. Radiat Res 165: $1-8$ to organise the study and recruited cases, FB-B (MD) and PP (MD) performed the pathological review of the cases, JP and JT interviewed cases and controls, JI (PhD) participated in the management of the study, and $\mathrm{EC}(\mathrm{PhD})$ contributed to the writing of the paper. All authors have reviewed and approved the manuscript.

\section{Conflict of interest}

The authors declare no conflict of interest.
Jurien de La Gravière M (2006) Les Essais Nucléaires Français Dans Le Pacifique. Délégué à la Sûreté Nucléaire de Défense: Paris

Kopecky KJ, Stepanenko V, Rivkind N, Voillequé P, Onstad L, Shakhtarin V, Parshkov E, Kulikov S, Lushnikov E, Abrosimov A, Troshin V, Romanova G, Doroschenko V, Proshin A, Tsyb A, Davis S (2006) Childhood thyroid cancer, radiation dose from Chernobyl, and dose uncertainties in Bryansk Oblast, Russia: a population-based case-control study. Radiat Res 166: 367 - 374

Land CE, Zhumadilov Z, Gusev BI, Hartshorne MH, Wiest PW, Woodward PW, Crooks LA, Luckyanov NK, Fillmore CM, Carr Z, Abisheva G, Beck HL, Bouville A, Langer J, Weinstock R, Gordeev KI, Shinkarev SM, Simon SL (2008) Ultrasound-detected thyroid nodule prevalence and radiation dose from fallout. Radiat Res 169: 373-383

Laudon F (1989) Le cancer en Polynésie Française. Direction de la Santé en Polynésie Française: Papeete, Tahiti

Likhtarov I, Kovgan L, Vavilov S, Chepurny M, Ron E, Lubin J, Bouville A Tronko N, Bogdanova T, Gulak L, Zablotska L, Howe G (2006) PostChernobyl thyroid cancers in Ukraine. Report 2: risk analysis. Radiat Res 166: $375-386$

Lyon JL, Alder SC, Stone BM, Scholl A, Reading JC, Holubkov R, Sheng X, White GL, Hegmann KT, Anspaugh L, Hoffman FO, Simon SL, Thomas B, Carroll R, Meikle AW (2006) Thyroid disease associated with exposure to the nevada nuclear weapons test site radiation a reevaluation based on corrected dosimetry and examination data. Epidemiology 17: 604-661

Manole D, Schildknecht B, Gosnell B, Adams E, Derwahl M (2001) Estrogen promotes growth of human thyroid tumor cells by differen molecular mechanisms. J Clin Endocrinol Metab 86: 1072-1777

Martin G (2007) Les Atolls de Mururoa et de Fangataufa (Polynésie Française). Les Expérimentations Nucléaires, Aspects Radiologiques. Commissariat à l'Energie Atomique: Saclay, France

Moolgavkar SH, Venzon DJ (1987) A method for computing profile likelihood based confidence bounds. Ann Stat 15: 346-359

Mushkacheva G, Rabinovich E, Privalov V, Povolotskaya S, Shorokhova V, Sokolova S, Turdakova V, Ryzhova E, Hall P, Schneider AB, Preston DL, Ron E (2006) thyroid abnormalities associated with protracted childhood exposure to $131 \mathrm{i}$ from atmospheric emissions from the mayak weapons facility in Russia. Radiat Res 166: 715-722

Preston DL, Lubin JH, Pierce DA, McConney ME (1993) EPICURE User's Guide. Hirosoft International Corp: Seattle, Washington

Ron E, Lubin JH, Shore RE, Mabuchi K, Modan B, Pottern LM, Schneider AB, Tucker MA, Boice JD (1995) Thyroid cancer after exposure to external radiation: a pooled analysis of seven studies Radiat Res 141: 259-277

Ron E (2007) Thyroid cancer incidence among people living in areas contaminated by radiation from the Chernobyl accident. Health Phys 93: $502-511$

Sack J (2003) Thyroid function in pregnancy-maternal-fetal relationship in health and disease. Pediatr Endocrinol Rev 1: 170-176

Sadetzki S, Chetrit A, Lubina A, Stovall M, Novikov I (2006) Risk of thyroid cancer after childhood exposure to ionizing radiation for tinea capitis. J Clin Endocrinol Metab 91: 4798-4804

Shipler DB, Napier BA, Farris WT, Freshley MD (1996) Hanford Environmental Dose Reconstruction Project-an overview. Health Phys 71: $532-544$.

Simon SL, Graham JC (1997) Findings from the first comprehensive radiological survey of the Republic of the Marshall Islands. Health Phys 73: $66-87$

Stepanenko V, Hoshi M, Bailiff IK, Ivannikov AI, Toyoda S, Yamamoto M, Simon SL, Matsuo M, Kawano N, Zhumalidov Z, Sasaki MS, Rosenson RI, 
Apsalikov KN (2006) Around Semipalatinsk nuclear test site: progress of dose estimation relevant to the consequences of nuclear tests. J Radiat Res (Tokyo) 47(Suppl. A): A1 - A13

Takahashi T, Fujimori K, Simon SL, Bechtner G, Edwards R, Trott KR (1999) Thyroid nodules, thyroid function and dietary iodine in the Marshall Islands. Int J Epidemiol 28: $742-749$

Takahashi T, Schoemaker MJ, Trott KR, Simon SL, Nakashima KFN, Fukao A, Saito H (2003) The relationship of thyroid cancer with radiation exposure from nuclear weapon testing in the Marshall Islands. J Epidemiol 13: 99-107

Tronko MD, Howe GR, Bogdanova TI, Bouville AC, Epstein OV, Brill AB, Likhtarev IA, Fink DJ, Markov VV, Greenebaum E, Olijnyk VA,
Masnyk IJ, Shpak VM, McConnell RJ, Tereshchenko VP, Robbins J, Zvinchuk OV, Zablotska LB, Hatch M, Luckyanov NK, Ron E, Thomas TL, Voillequé PG, Beebe GW (2006) A cohort study of thyroid cancer and other thyroid diseases after the Chernobyl accident: thyroid cancer in Ukraine detected during first screening. J Natl Cancer Inst 98: $897-903$

(c) (1) (2) This work is licensed under the Creative Commons CY NC SA Attribution-NonCommercial-Share Alike 3.0 Unported License. To view a copy of this license, visit http://creativecommons. org/licenses/by-nc-sa/3.0/ 